\title{
Physiological Changes and Blood Flow in Murrah Buffaloes during Summer and Winter Season
}

\author{
A.K. Singh, Rajni Devi, Y. Kumar, Parveen Kumar and R.C. Upadhyay \\ Climate Resilient Livestock Research Centre, National Dairy Research Institute, Karnal-132 001 (Haryana), \\ India
}

\begin{abstract}
Present study was designed to investigate the changes in physiological reactions and blood flow during different seasons in Murrah buffaloes. Six Murrah buffalo heifers of 18-24 months were selected as experimental animals. The respiration rate (RR), heart rate (HR) and blood pressure was measured through BPL-Excello multi parameter monitor. Rectal temperatures were recorded with electronic thermometer. Skin surface temperatures at the different body sites were recorded using infrared thermometer (Metravi MT-2). The blood flow was measured on Perimed Multichannel Laser Doppler system using skin perfusion probe 408 at dorsal region, abdomen region and middle ear. Results showed a significant difference for respiration rate $(P<0.001)$; rectal temperature $(P<0.05)$ and heart rate $(P<0.001)$ during summer and winter season. The mean blood pressure was $93.74 / 186.36 \mathrm{mmHg}$ in summer and $97.40 / 198.08 \mathrm{mmHg}$ in winter, respectively. In the present experiment, both diastolic and systolic pressure differed significantly $(P<0.001)$ during different seasons. The mean skin surface temperature in summer was $37.03 \pm 0.39$, $36.12 \pm 0.27$ and $33.15 \pm 0.98^{\circ} \mathrm{C}$ at dorsal, abdomen and middle ear, respectively; whereas, during winter it was $29.87 \pm 0.69,29.92 \pm 0.40$ and $23.82 \pm 1.12^{\circ} \mathrm{C}$ at dorsal, abdomen and middle ear, respectively. The skin surface temperature among the different parts of the body differed significantly $(P<0.001)$. During summer, the mean blood flow was $4.71 \pm 0.49,14.85 \pm 1.63$ and $16.72 \pm 1.47 \mathrm{PU}$; whereas, during winter, it was low, $1.10 \pm 0.16,8.96 \pm 0.58$ and $12.16 \pm 0.95 \mathrm{PU}$ at dorsal, abdomen and middle ear, respectively. The difference in the blood flow among the different parts of the body differed significantly $(\mathrm{P}<0.001)$ in summer and winter. The results indicated that blood flow was positively correlated with temperature of the body parts and it varied in different seasons. This study concluded that, summer stress evokes a series of physiological changes in the Murrah buffalo's, which affects production during summer season.
\end{abstract}

Keywords: Blood flow, Murrah buffalo, Physiological responses, Summer, Winter.

\section{INTRODUCTION}

India possesses highest number of buffaloes, milk production and best milch breeds in the world [1]. India has about 102.4 million buffaloes, which represents 56.5 percent of the world buffalo population. Buffaloes are the principal dairy animal in the developing countries of Asia and are the mainstay of Indian dairy industry contributing over $60 \%$ of the total milk production. They also contribute significantly to the meat industry in India, where cattle slaughter is ban. Air temperature $\left(13-18{ }^{\circ} \mathrm{C}\right), \mathrm{RH}(55-65 \%)$ and wind velocity $(5-8 \mathrm{~km} / \mathrm{h})$ are the optimum conditions for buffaloes as suggested by Payne and Payne [2]. Murrah buffalo has only $1 / 8^{\text {th }}$ the numbers of sweat glands per unit area of skin compared to zebu cattle and therefore rely on wallowing or wetting to the skin during heat conditions to reduce the heat load [3]. The animals that are exposed to chronic stress, try to acclimatize in the adverse condition with the help of phenotypic responses to environmental changes [4]. When the heat load of an animal is greater than its capacity to lose heat [5], a portion of the metabolizable energy

*Address correspondence to this author at the Climate Resilient Livestock Research Centre, National Dairy Research Institute, Karnal-132 001 (Haryana), India; Tel: +91-9896364644; Fax: +91-184-2250042;

E-mail: upadhyay.ramesh@gmail.com typically used for production must be diverted to assure thermal balance. Therefore, selection for tolerance to environmental stress has traditionally resulted in reduced productivity [6]. Buffaloes have acquired several morphological features, which reinforce their ability to thrive well in hot-humid conditions. The melanin-pigmented skin of buffaloes protect against ultraviolet rays. Hair density in adult buffalo is only oneeighth of that in cattle [7], thus facilitating dissipation of heat by convection and radiation. Further, the number of sebaceous glands is lower in buffalo than in cattle; however, sebum secretion shows an opposite trend [7]. The sebum provides effective protection to the skin in the mud. The skin in buffaloes is thicker than that of cattle and protect bare body surface of buffalo from harmful mechanical and chemical agents, in water and mud while swimming and wallowing [8].

Thermal stress is a concern for all livestock production systems, its effects have been studied because of the profound and readily apparent negative impact on production and health. Although buffaloes are well adapted to hot/humid conditions, their heat tolerance capacity is low primarily due to low sweat gland density. They cool their body effectively under shade; however, they resort to moderate levels of sweating, open mouth panting and wallowing under excess thermal loads. Exposure to high ambient 
temperature is the major constraint on buffalo productivity in hot climatic areas. An increase in body temperature of around $1.0^{\circ} \mathrm{C}$ may result in detectable, deleterious effects on metabolism, tissue integrity and a significant depression in production [9]. The air temperature rise beyond the upper limit of thermoneutrality range involves physical regulation of body temperature by the redistribution of cardiac output and blood flow to skin and extremities. Therefore, present study was undertaken to measure the seasonal influence (summer and winter) on blood flow and different physiological reactions in Murrah buffaloes.

\section{MATERIALS AND METHODS}

\section{Selection, Feeding and Maintenance of Animals}

The present study was carried out in Murrah buffaloes at NDRI, Karnal, situated at an altitude of 250 meter above mean sea level, latitude and longitude position being $29^{\circ} 42^{\prime \prime} \mathrm{N}$ and $79^{\circ} 54^{\prime \prime} \mathrm{E}$ respectively, with ambient temperature in summer as high as $45^{\circ} \mathrm{C}$ and in winter as low as $0^{\circ} \mathrm{C}$. The experiment was conducted on six Murrah buffalo heifers (18-24 months) selected from NDRI herd. The experimental animals were maintained as per standard feeding and management practices followed at National Dairy Research Institute, Karnal, India. This consists of feeding ad libitum roughages and water; concentrates mixture as per Kearl (1982) feeding standard. Concentrate mixture composited of mustard cake, maize, wheat bran, rice bran, mineral mixture and salt. The crude protein (CP) and total digestible nutrients (TDN) of diet was $12 \%$ and $60 \%$, respectively.

\section{Estimation of Physiological Parameters}

The respiration rate $(R R)$, heart rate $(H R)$ and blood pressure was measured through multi parameter monitor (BPL-Excello). Rectal temperatures were recorded with electronic thermometer. Skin surface temperatures at the different sites were recorded using infrared thermometer (Metravi MT-2). Air temperature was measured by a mercury thermometer; relative humidity- by a psychrometer (measuring the difference between the dry and wet bulb temperature). The abiotic factors were registered immediately after each measurement of the physiological parameters.

\section{Estimation of Blood Flow}

The blood flow was measured on Perimed Multichannel Laser Doppler system (Perimed AB,
Jarfalla, Sweden) using skin perfusion probe 408 at dorsal region, abdomen region and ear (middle).

\section{Statistical Analysis}

The data analysis was done using SAS software, Version (9.1) of the SAS System for Window, Copyright $^{\odot}$ (2011) SAS Institute Inc., Cary, NC, USA. Data from different experiments are presented as mean $\pm S E$. The pair-wise comparison of means was carried out using Tukey's multiple comparison test. The difference at $\mathrm{P} \leq 0.05$ was considered to be statistically significant. The following statistical model was used to estimate seasonal effects:

$$
Y_{i j k}=\mu+S_{i}+B_{j}+e_{i j k}
$$

Where, $\mathrm{Y}_{\mathrm{ijk}}=$ dependent variable; $\mu=$ overall mean of the population; $S_{i}=$ mean effect of the seasons $(i=$ $1, \ldots .2) ; B_{j}=$ mean effect of the body parts $(j=1, \ldots .3)$; and $e_{i j k}=$ unexplained residual element assumed to be independent and normally distributed.

\section{RESULTS AND DISCUSSION}

\section{Respiration Rate}

Respiration rate was $18.77 \pm 1.25$ and $12.29 \pm 1.97$ breath/minute during summer and winter, respectively. The respiration rate was statistically different $(P<0.05)$ during different seasons in Murrah buffalo (Figure 1). Respiration rate per minute was increases during summer as compared to winter season. Increased respiration is an attempt to increase heat loss by evaporative cooling.

The increase in respiration rate in summer as compared to winter may be due to the more demand of oxygen by the tissues in stressful condition. The results of respiration rate are in agreement with the observations of Koga et al. [10], Gudev et al. [11] and Lallawmkimi et al. [12]. Robinson et al. [13] also reported that respiration rate significantly increased in every group of cattle exposed to gradually increased test-temperatures. Similarly, McDowell [14] reported that a low respiratory rate under hot weather identifies animals with lesser discomfort. This fact is evident when comparing respiration rates of Bos taurus versus Bos indicus under hot summer weather conditions where Bos indicus (zebu) cattle maintain lower respiration rates.

Silanikove [15] reported that measuring respiration rate appears to be the most accessible and easiest 


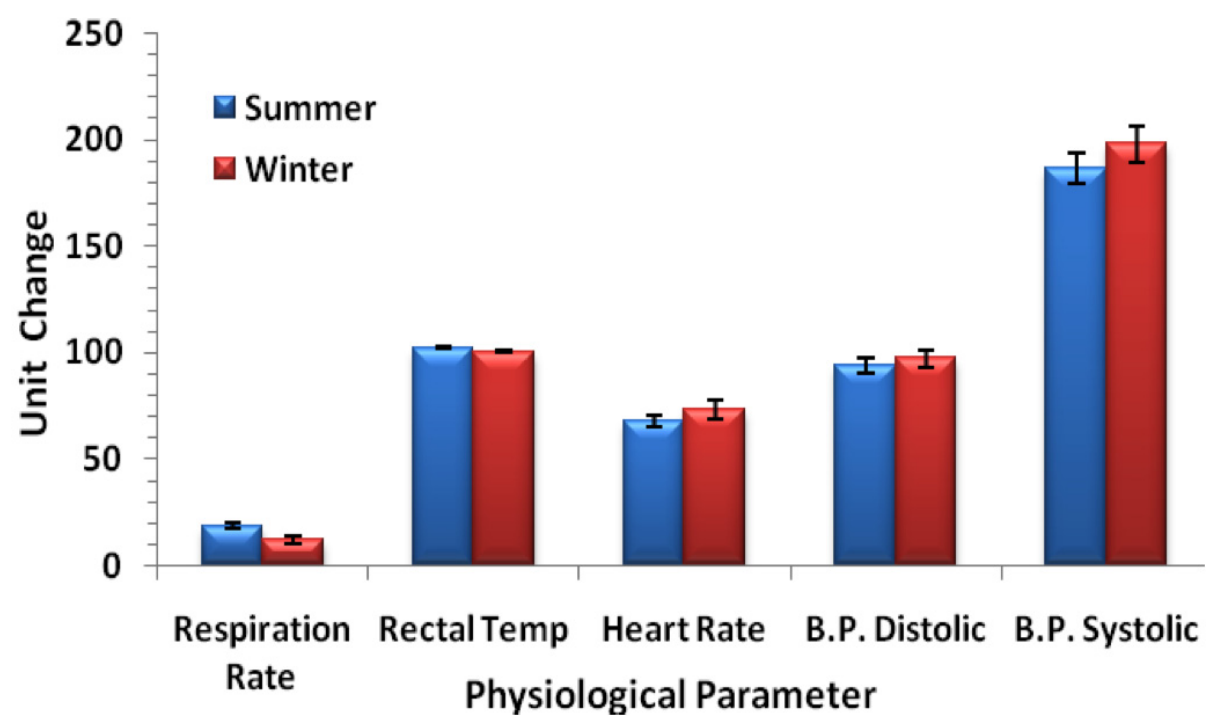

Figure 1: Effect of different seasons on different physiological parameter in Murrah buffalo.

approach for evaluating the degree of heat stress in farm animals (low: $40-60$ breaths per min, medium high: $60-80$, high: $80-120$, and severe stress: above 150 breaths per minute in cattle. Dandage [16] reported that there is increased in RR at the end of four hours exposure in climatic chamber at $40^{\circ} \mathrm{C}$ and $50 \% \mathrm{RH}$ and also in the extreme seasons (winter and summer) of the year on Sahiwal, Karan Fries and Murrah buffaloes. Respiratory rate increases as stressors cause an animal to maintained homeothermy by dissipating excessive heat when other avenues (conduction, convection and radiation) becomes inadequate. Respiratory rate is influenced by ambient temperature, solar radiation, relative humidity and wind speed. Among these, ambient temperature has been found to be the most influential factor.

\section{Rectal Temperature}

The rectal temperatures of experimental animals are depicted graphically in Figure 1. Rectal temperature was $102.52 \pm 0.25$ and $100.68 \pm 0.19{ }^{\circ} \mathrm{C}$ during summer and winter, respectively. There was significant increase $(P<0.05)$ in rectal temperature during summer as compared to winter.

Deviation from the normal physiological rectal temperature has been considered as an index of discomfort. Rectal temperature is considered as a good index of body temperature even though there is a considerable variation in different parts of the body core at different times of the day [17]. RT is an indicator of thermal balance and may be effective in quantifying the harshness of the thermal environment [15]. The respiration rates in present study are in general agreement with the observations of Moran [18] who reported that in buffaloes there is an increased in rectal temperature and skin temperature under solar radiation but in contrast, the rectal temperature of buffaloes decreases rapidly when they are moved into the shade [8].

Koubkova et al. [19] also reported significant increase in rectal temperature from 37.3 to $39.3^{\circ} \mathrm{C}$ in high yielding Holstein cows exposed to high temperature. Bernabucci et al. [20] assessed the effects of hot season $\left(39.5 \pm 0.2^{\circ} \mathrm{C}\right)$ in transition dairy cows and found that rectal temperature differed significantly $\left(39.5\right.$ vs $\left.39.1^{\circ} \mathrm{C}, \mathrm{P}<0.01\right)$. Dandage [16] reported positive correlation between $\mathrm{RT}$, humidity and other physiological responses in Murrah buffaloes, Karan Fries and crossbred cattle. Changes in rectal temperature have been considered an index of heat storage in large animals and other mammals. Core body temperature indicates the extent to which the thermoregulatory mechanisms have been successful in maintaining a thermal balance. The change in RT induces a marked increase in blood flow from the body core to the surface, for enhanced dissipation of heat from the skin surface.

\section{Heart Rate (HR)}

Alteration in heart rate is also one of the major indicators of stress. In present experiments, mean heart rate was $67.65 \pm 2.8$ and $73.43 \pm 4.21$ beats/minute during summer and winter, respectively; and differences were statistically significant $(P<0.001)$ during summer and winter season (Figure 1). 
Increase in heart rate is attributed to two causes. One is the increase in muscular activity controlling the rate of respiration, concurrent with elevated respiration rate. The second is the reduction in resistance of peripheral vascular beds and arteriovenous anastomoses. The results of the present study are in general agreement with Upadhyay and Rao [21] who reported that under stressful conditions, the heart rate increases from 55 to 98 beats $/ \mathrm{min}$. Aggarwal and Upadhyay [22] also reported an increase in heart rate from 61 to 79 beats/min in Sahiwal and 67 to 86 beats/min in crossbred after four hours of solar radiation exposure. Lal et al. [23] found a significant increase in heart rate with an increase in ambient temperature and relative humidity. Badreldin and Ghany [8] also reported that buffaloes have a lower level of heart rate than cattle and exhibit noticeable more stress in summer. Patel et al. [24] reported that the correlation between the RR and heart rate was positive, high and significant in Jersey crosses $\left(r^{2}=\right.$ $0.61 ; P<0.05)$. While this relationship was still higher and highly significant $\left(r^{2}=0.87 ; P<0.01\right)$ in Holstein crosses. Blackshaw and Blackshaw [25] reported a significant rise in heart rate and respiration rate but insignificant rise in rectal temperature during heat stress in cattle. Mishra et al. [26] reported a correlation $\left(r^{2}=0.71\right.$, between AT and PR; and $r^{2}=-0.56$, between $\mathrm{RH}$ and $\mathrm{PR}$ ) in crossbred heifers. Banerjee and Ashutosh [27] reported a positive correlation between $\mathrm{RT}, \mathrm{PR}, \mathrm{ST}, \mathrm{RR}$ and antioxidant status in climatic chamber exposure studies.

\section{Blood Pressure}

The diastolic pressure was $93.74 \pm 3.6 \& 97.40 \pm 3.92$ $\mathrm{mmHg}$ and systolic pressure was $186.36 \pm 7.27$ \&
$198.08 \pm 8.90 \mathrm{mmHg}$ during summer and winter season, respectively. The mean blood pressure was 93.74/186.36 $\mathrm{mmHg}$ in summer and 97.40/198.08 $\mathrm{mmHg}$ in winter, respectively. In the present experiment, both diastolic and systolic pressure differed significantly $(P<0.001)$ during different seasons (Figure 1).

The values of blood pressure in buffalo heifers are in agreements with the value for BP reported by Singh et al. [28, 29]. Similar to present results, Whittow [30] reported significantly lower mean blood pressure, in the hot dry environment than they were at $15^{\circ} \mathrm{C}$. The increase in systemic arterial blood pressure during summer was attributed to the concomitant increase in cardiac output because the total peripheral resistance diminished. The increase in the cardiac output was the result of an increased heart rate. Therefore, we can say that the work of heart was increased during summer. These results seemed to be consistent with the hypothesis that a peripheral vasodilatation and an increased venous return occurred in the hot dry environment [30].

\section{Skin Surface Temperature}

The skin surface temperature in summer was $37.03 \pm 0.39,36.12 \pm 0.27$ and $33.15 \pm 0.98^{\circ} \mathrm{C}$ at dorsal, abdomen and middle ear, respectively; whereas, during winter it was $29.87 \pm 0.69,29.92 \pm 0.40$ and $23.82 \pm 1.12^{\circ} \mathrm{C}$ at dorsal, abdomen and middle ear, respectively. The skin surface temperature at the different parts of body differed significantly $(P<0.001)$. Skin surface temperature also differed significantly $(P<0.001)$ during different seasons. However, there were no significant $(P=0.544)$ interaction between different body part and season (Figure 2).

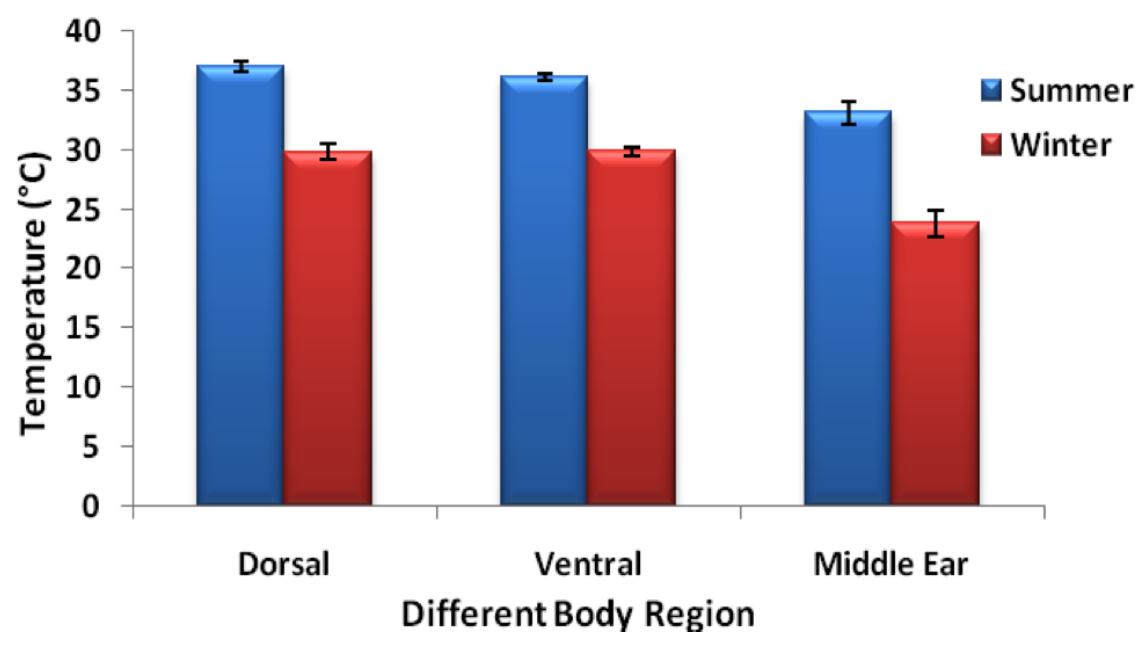

Figure 2: Effect of different seasons on body surface temperature $\left({ }^{\circ} \mathrm{C}\right)$ in the different body region of Murrah buffalo. 
The outermost surface of an animal skin is the transducing surface across which the environment interacts with the internal physiology of the animal. In the present study, we recorded different temperatures at various parts of the body in different seasons (Figure 2). The results of the present study are in general agreement with Koga et al. [10] who reported a significant increase in skin temperature of buffaloes as compared to cattle with increased environmental temperature. Ashour [31] also reported that the skin temperature increases due to high ambient temperature that leads to increased heat storage in the body of calves. Similarly, Das et al. [3] reported a diurnal variation in skin temperature of different body parts in response to heat stress in male buffalo calves. A significant variation exists in surface temperature of ear and rump at noon as compared to morning in exposed and unexposed calves [32].

Robertshaw [33] reported that the relationship between environmental temperature and skin temperature in cattle is closer with the skin of the limbs than the skin of thorax, where variation in blood flow to the skin seems to be minimal. In the present study, skin on dorsal body region seems to be much more active in heat dissipation as compared with that of the ventral and ears.

\section{Blood Flow}

The blood flow in the different part of body during different seasons in Murrah buffalo are depicted graphically in Figure 3. During summer, the mean blood flow was $4.71 \pm 0.49,14.85 \pm 1.63$ and $16.72 \pm 1.47$ PU at dorsal, abdomen and ear part of body, respectively. While during winter, it was reduced to $1.10 \pm 0.16,8.96 \pm 0.58$ and $12.16 \pm 0.95 \mathrm{PU}$ at dorsal, abdomen and middle ear part of body, respectively. The difference in the blood flow among the different part of body was differed significantly $(P<0.001)$ in summer and winter. Blood flow also differed significantly $(P<0.001)$ during different seasons. However, there is not a significant $(P=0.544)$ interaction between different body part and season.

The results of the present study are in general agreement with Marai et al. [34] who reported that increase in environmental temperature increases blood flow from the core to the surface because of it more heat is lost by sensible (loss by conduction, convention and radiation) and insensible (loss by diffusion water from the skin) means. Silanikove [15] also reported that heat stress increase cardiac output and cutaneous blood flow, due to blood redistribution from deep splanchnic to more peripheral body regions. West [35] reported that sweating, high respiration rate, vasodilatation with increased blood flow to skin surface, elevated rectal temperature and altered water metabolism are the physiological responses that are associated with negative impacts of heat stress on production and reproduction in dairy animals. In summer, thermoregulation requires increasing blood flow to the skin surfaces where evaporation occurs. This means a concomitant decrease in blood flow and hence movement of water and nutrients to and from organs of high metabolic rate such as the digestive tract [36] and reproductive organs [37]. Such adjustments in the partitioning of water and blood flow away from energy metabolism to thermoregulation would act to dampen the metabolism of production. In the present study, blood flow in different body regions were more during summer as compared to winter, which may suggest that in summer animal divert

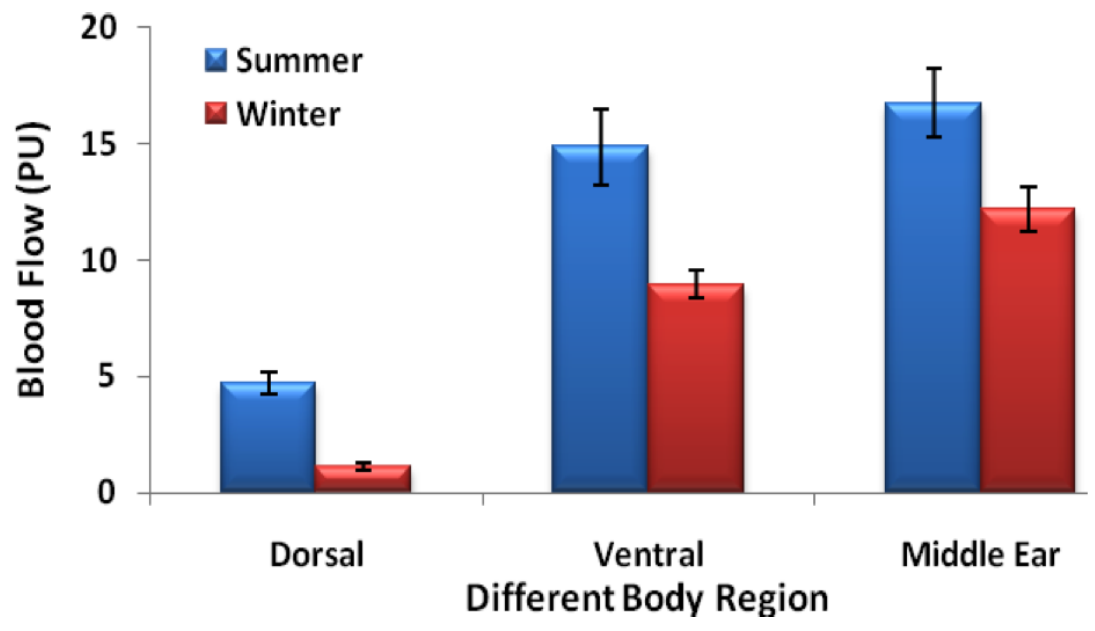

Figure 3: Effect of different seasons on blood flow (PU) in the different body region of Murrah buffalo. 
greater blood volume to skin for heat dissipation to maintain homeostasis.

\section{CONCLUSION}

Physiological reactions like respiration rate, rectal temperature, heart rate, blood pressure, skin temperature and blood flow give an immediate response to climatic stress and thus to the level of comfort of the animal. Therefore, these parameters are important in measuring the comfort level of the animal and thus the production potential of the animal. Buffaloes have poor heat tolerance capacity compared to other domestic ruminants, and are more prone to heat stress due to scarcely distributed sweat glands, dark body colour and sparse hair on the body surface. In the present study, blood flow in different body regions and different physiological reactions were higher during summer as compared to winter, which may suggest that in summer animal divert their blood flow to maintain homeostasis instead of production. Therefore, we may conclude that summer season is more stressful as compared to winter season, which affects the production in summer season. This study will provide insight for developing new strategies to ameliorate the economic impact of seasonal stress and help to improve the welfare and efficiency of Murrah buffalo's production.

\section{ACKNOWELDEGEMENTS}

The authors express sincere thanks to the Director, NDRI, Karnal for providing necessary facilities for research. The financial assistance for the research work was provided from National Initiative on Climate Resilient Agriculture (NICRA) project of Indian Council of Agricultural Research (ICAR), New Delhi.

\section{REFERENCES}

[1] FAO. United Nations Food and Agriculture Organisation, 2008 production year book 2010 .

[2] Payne JM, Payne S. Indicators of blood enzymes. In: The metabolic profile test. (Payne JM, Payne S, Eds.) Oxford university press. Oxford, New York, Tokyo 1987; pp. 92-100.

[3] Das SK, Upadhyay RC, Madan ML. Heat stress in Murrah buffalo calves. Livestock Prodn Sci 1999; 61: 71-78. http://dx.doi.org/10.1016/S0301-6226(99)00040-8

[4] Collier RJ, Dahl GE, Van Baale MJ. Major advances associated with environmental effects on dairy cattle. J Dairy Sci 2006; 89: 1244-53.

http://dx.doi.org/10.3168/jds.S0022-0302(06)72193-2

[5] Wagner PE. Heat stress on dairy cows. Dairy Franklin Country Publishers 2001.

[6] Smith J, Harner J, Dunham D, Stevenson J, Shirley J, Stokka G, Meyer M. Coping with summer weather: Dairy management strategies to control heat stress. Kansas State University, Manhattan, KS 2000.
[7]

Hafez ESE, Badreldin AL, Shafie MM. Skin structure of Ezyptian buffalo and cattle with particular references to sweat glands. J Agric Sci 1955; 46: 19-30. http://dx.doi.org/10.1017/S0021859600039587

[8] Badreldin AL, Ghany MA. Species and breed differences in the thermal reaction mechanism. J Agric Sci 1954; 44: 16064.

http://dx.doi.org/10.1017/S0021859600046244

[9] McDowell RE, Hooven NW, Camoens JK. Effects of climate on performance of Holsteins in first lactation. J Dairy Sci 1976; 59: 965-73.

http://dx.doi.org/10.3168/jds.S0022-0302(76)84305-6

[10] Koga A, Sugiyama M, Del Barrio AN, Lapitan RM, Arenda BR, Robles AY, Cruz LC, Kanai Y. Comparison of the thermoregulatory response of buffaloes and tropical cattle, using fluctuations in rectal temperature, skin temperature and haematocrit as an index. J Agric Sci 2004; 142: 351-55. http://dx.doi.org/10.1017/S0021859604004216

[11] Gudev D, Popova-Ralcheva S, Moneva P, Aleksiev Y, Peeva $T$, llieva $Y$, Penchev P. Effect of heat-stress on some physiological and biochemical parameters in buffaloes. Ital $\mathrm{J}$ Anim Sci 2007; 6(2): 1325-28.

[12] Lallawmkimi MC, Singh SV, De S, Hooda OK, Upadhyay RC Singh AK, Vaidya MM. HSP 72 expression and antioxidant enzymes in Murrah buffaloes during heat exposure in climatic chamber. Indian J Anim Sci 2012; 82 (3): 268-73.

[13] Robinson JB, Ames DR, Milliken GA. Heat production of cattle acclimated to cold, thermoneutrality and heat when exposed to thermoneutrality and heat stress. J Anim Sci 1986; 62: 1434-40.

[14] McDowell RE. Improvement of livestock production in warm climates. W.H. Freeman and Co., San Francisco, CA 1972.

[15] Silanikove N. Effects of heat stress on the welfare of extensively managed domestic ruminants. Livest Prod Sci 2000; 67: 1-18.

http://dx.doi.org/10.1016/S0301-6226(00)00162-7

[16] Dandage SD. Estimates of thermal load and heat exchange in cattle and buffaloes. M.V.Sc. Thesis submitted to NDRI Deemed University, Karnal (Haryana), India 2009.

[17] Srikandakumar A, Johnson EH. Effect of heat stress on milk production, rectal temperature, respiratory rate and blood chemistry in Holstein, Jersey and Australian Milking Zebu cows. Trop Anim Health Prod 2004; 36: 685-92. http://dx.doi.org/10.1023/B:TROP.0000042868.76914.a9

[18] Moran JB. Heat tolerance of brahman cross, buffalo, banteny and shorthorn steers during exposure to sun and as a result of exercise. Aust J Agril Res 1973; 24(5): 775-82. http://dx.doi.org/10.1071/AR9730775

[19] Koubkova M, Knizkova I, Munc P, Hartlova H, Flusser J, Dolezal O. Influence of high environmental temperatures and evaporative cooling on some physiological, hematological and biochemical parameters in high-yielding dairy cows. Czech J Anim Sci 2002; 47(8): 309-18.

[20] Bernabucci U, Ranchi B, Lacetara N, Nardone A. Markers of oxidative status in plasma and erythrocytes of transition dairy cows during hot season. J Dairy Sci 2002; 85: 2173-79. http://dx.doi.org/10.3168/jds.S0022-0302(02)74296-3

[21] Upadhyay RC, Rao MVN. Responses of buffaloes to heavy working loads under tropical conditions. Livestock Prod Sci 1985; 13: 199-203. http://dx.doi.org/10.1016/0301-6226(85)90022-3

[22] Aggarwal A, Upadhyay RC. Pulmonary and skin evaporative heat loss during exercise in hot dry conditions in crossbreds. Indian J Anim Sci 1997; 67(1): 51-53.

[23] Lal SN, Verma DN, Hussain K. Effect of air temperature and humidity on the feed consumption, cardio-respiratory responses and milk. Milk production in Haryana cows. Indian Vet J 1987; 64: 115-21. 
[24] Patel AN, Dave AD, Patel KS, Patel JP. Comparative study of physiological responses of Kankrej $x$ Jersey $\left(F_{1}\right)$ AND Kankrej $x$ Holstein Friesian $\left(F_{2}\right)$ Calves. Indian J Dairy Sci 1985; 38: 174.

[25] Blackshaw JK, Blackshaw AW. Heat stress in cattle and effect of shade on the production and behavior, A Review. Aust J Exp Agri 1994; 34: 285-95. http://dx.doi.org/10.1071/EA9940285

[26] Mishra L, Mohanty A, Nayak NR, Prusty BM, Mishra MS. Effects of climatic stress on the physiological reactions of crossbred and purebred animals. Indian Vet J 1995; 72: 92934.

[27] Banerjee D, Ashutosh. Effect of thermal exposure on diurnal rythms of physiological parameters and feed,water intake in Tharparkar and Karan Fries heifers. Biol Rhythm Res 2011; 42(1): 39-51.

http://dx.doi.org/10.1080/09291011003726490

[28] Singh DV, Singh RV, Sodhi SPS. Effect of blood transfusion in combination with Dextran-40 and hypertonic Saline Solution on cardiopulmonary haemo-dynamics of endotoxic shock in buffalo calves. Vet Res Commun 2005; 29: 421-30. http://dx.doi.org/10.1007/s11259-005-1434-x

[29] Singh D, Bansal SK, Ghumman GS. Effect of flunixin meglumine alone and in combination on haemodynamics during bovine endotoxic shock and after treatment. J Biomed Sci Eng 2011; 4: 29-33.

http://dx.doi.org/10.4236/jbise.2011.41004
[30] Whittow GC. The effect of hyperthermia on the systemic and pulmonary circulation of the ox (Bos taurus). Quart J Exp Physio 1965; 50: 300.

[31] Ashour G. Impact of environmental temperature on heat storage in the body of calf. J Anim Prod 1993; 64: 716.

[32] Spain JN, Spiers DE. Effect of environmental temperature variation on ear and rump of buffalo calves. J Dairy Sci 1996; 79: 639.

http://dx.doi.org/10.3168/jds.S0022-0302(96)76409-3

[33] Robertshaw D. Heat loss of cattle. Stress physiology in Livestock Basic Principles, PP SS (M K Yousef) Florida CRC Press 1985

[34] Marai IFM, El-Darawany AA, Fadiel A, Abdel-Hafez MAM. Physiological traits as affected by heat stress in sheep. A review. Small Ruminant Res 2007; 71: 1-12. http://dx.doi.org/10.1016/j.smallrumres.2006.10.003

[35] West JW. Nutritional strategies for managing the heat stressed dairy cow. J Anim Sci 1999; 77(Suppl. 2): 21-35.

[36] Engelhardt WV, Hales JRS. Partition of capillary blood flow in rumen, reticulum, and omasum of sheep. Amer J Phiol 1977; 232: E53.

[37] Roman-Ponce $\mathrm{H}$, Thatcher WW, Caton D, Barron DH, Wilcox CJ. Thermal stress on uterine blood flow in dairy cows. $J$ Anita Sci 1978; 46: 175. 